\title{
Wprowadzenie: Reforma szkolnictwa wyższego w Polsce i jej wyzwania. Jak stopniowa dehermetyzacja systemu prowadzi do jego stratyfikacji
}

\section{Uwagi wstępne: czego uczą nas wcześniejsze reformy}

W Polsce, podobnie jak w Europie Zachodniej, funkcjonują dzisiaj dwa - pozostające ze sobą w głębokim konflikcie - paradygmaty myślenia o misji uniwersytetu i roli szkolnictwa wyższego ${ }^{1}$. Z jednej strony paradygmat w postaci praktycznego zestawu globalnych i ponadnarodowych rekomendacji (Banku Światowego, OECD i Komisji Europejskiej) dotyczących kierunków systemowych reform szkolnictwa wyższego, silnie wspierany przez idee Nowego Zarządzania Publicznego (New Public Management). Z drugiej strony paradygmat tradycyjnego myślenia wspólnoty akademickiej o akademickich instytucjach, głęboko zakorzeniony w wartościach i normach elitarnego, humboldtowskiego uniwersytetu (Nóvoa i Lawn 2002; Ramirez 2006; Antonowicz 2015). Oba paradygmaty w różnych momentach historycznych z różną siłą się ze sobą ścierają.

W Polsce okresem ich wyjątkowo silnej, publicznej konfrontacji były lata 2009-2011. Zmagania między nimi prowadzą w wielu systemach do długotrwałych konfliktów wokół alternatywnych zasad instytucjonalnych (March i Olsen 1989). Pierwszy paradygmat wspiera władza redystrybucji publicznych zasobów

\footnotetext{
${ }^{1}$ Przy pisaniu tego wprowadzenia korzystałem z licznych tekstów z ostatnich lat, przede wszystkim z książki Uniwersytet $w$ dobie przemian. Instytucje $i$ kadra akademicka $w$ warunkach rosnacej konkurencji (Warszawa: PWN, 2015, s. 554). Nie bez wpływu na jego kształt pozostaje również wspólna praca z koleżankami i kolegami w ramach Ustawy 2.0: Projekt założeń do ustawy Prawo o szkolnictwie wyższym, Marek Kwiek z Zespołem, Poznań: Uniwersytet im. Adama Mickiewicza, 2016, s. 191.
} 
i siła zmian prawnych, a drugi - moc akademickich tradycji. Założenia rządowe do poprzedniej fali reform odwoływały się do paradygmatu globalnego, w tym do publikacji OECD na temat Polski (Fulton, Santiago, Edquist, El-Khawas i Hackl 2007), a założenia do reform przygotowane przez wspólnotę akademicką (KRASP 2009) zostały sformułowane w tradycyjnym paradygmacie wspólnoty akademickiej. W 2009 r. pojawiły się dwie równoległe ścieżki prac nad reformą: ścieżka ustawodawców i ekspertów (EY/IBNGR 2010) oraz ścieżka wspólnoty akademickiej, skupionej przede wszystkim wokół Konferencji Rektorów Akademickich Szkół Polskich (KRASP). Powstały dwa równoległe projekty ustaw i dwie strategie rozwoju szkolnictwa wyższego. Kulminacją sporów o przyszły kształt reform stał się okres publicznych prezentacji i dyskusji obu strategii na przełomie 2009 i 2010 r. Jednakże, paradoksalnie, w momencie najbardziej gorących publicznych dyskusji, kształt reformy i kształt wszystkich ustaw był już przesądzony.

Tym razem, jak się wydaje, jest inaczej - pojawiły się wielomiesięczne konsultacje: konferencje i spotkania organizowane pod hasłem „Ustawa 2.0”; ich poziom merytoryczny był wysoki, a partycypacyjny model wprowadzania zmian legislacyjnych (zob. tekst Jarosława Górniaka w tym tomie) pozwolił na zaangażowanie w dyskusje o reformach szerokiego grona osób spośród kadry akademickiej. Prezentowany, jubileuszowy tom Nauki i Szkolnictwa Wyższego jest w zamierzeniu ważnym elementem debaty o kształcie aktualnych i przyszłych reform, w której udział biorą najznamienitsze umysły zaangażowane dzisiaj w myślenie o reformach, stojące często od wielu lat po przeciwnych stronach toczącego się szerszego sporu.

Musimy zatem pamiętać o jednym istotnym wymiarze: reformy w Polsce są częścią globalnych zmian, a w tle pozostają ewoluujące relacje państwo - akademia (Kwiek 2015b). W Europie Zachodniej od trzech dekad trwają renegocjacje relacji między państwem a systemami szkolnictwa wyższego (Neave i van Vught 1991; Gornitzka, Kogan i Amaral 2005). W związku z tym, że większość najbardziej rozwiniętych gospodarek europejskich w coraz większym stopniu opiera się na wiedzy, nacisk na głębokie reformy instytucji uniwersytetu - i całego systemu szkolnictwa wyższego - jest coraz silniejszy. Jednocześnie wiedza, w tym wiedza akademicka, zostaje umiejscowiona w samym centrum podstawowych wyzwań gospodarczych nowoczesnego społeczeństwa (Leydesdorff 2006; Bonaccorsi i Doraio 2007). Relacje między państwem (i społeczeństwem) a uniwersytetem są dziś zatem permanentnie redefiniowane, a dynamikę zachodzących zmian w najszerszym ujęciu można określić jako „poszukiwanie nowego paktu między uniwersytetem a jego otoczeniem" (Maassen i Olsen 2007). Takie same procesy zachodzą dziś w Polsce, chociaż rzadko są w taki sposób konceptualizowane.

Zmieniające się społeczne, gospodarcze, kulturowe i prawne otoczenie europejskich instytucji szkolnictwa wyższego coraz bardziej zmusza je do funkcjonowania w stanie permanentnej adaptacji do zmian sposobów finansowania i zarządzania (Clark 1998; Shattock 2009; Krücken, Kosmützky i Torka 2007; Maassen 2008; 
Paradeise, Reale, Bleiklie i Ferlie 2009). Przykłady głównych systemów szkolnictwa wyższego w Europie pokazują, że reformowanie uniwersytetów prowadzi do ich kolejnych reform (Maassen i Olsen 2007; Clancy i Dill 2009) - a nie do ich ostatecznego zreformowania. Musimy nauczyć się żyć z reformami, ponieważ okresy stabilności są w Europie bardziej wyjątkiem niż regułą, a okresy reform w większości krajów trwają nieprzerwanie. Podobnie dzieje się w Polsce: poprzednia fala reform $\mathrm{z}$ lat 2009-2011 nie była postrzegana przez ustawodawców i reformatorów jako ostatnia. Wiadomo było, że będzie ona pierwszym, wstępnym etapem, zgodnie z bardziej ogólnymi obserwacjami z obszaru badań organizacji, według których „reformy instytucjonalne rodzą nowe żądania reform, a nie sprawiają, że dalsze reformy stają się zbędne" (Olsen 1998: 322).

Względnie stabilne otoczenie społeczne i ekonomiczne (choć nie polityczne) polskich uniwersytetów w latach 80. XX wieku ulegało w latach 90. stopniowej dezintegracji, co doprowadziło do pojawienia się nowych instytucjonalnych (oraz indywidualnych) „strategii przetrwania”. Nowe normy i zachowania instytucjonalne (oraz indywidualne) pojawily się wraz z instytucjonalną autonomią odzyskaną bezpośrednio po upadku komunizmu. Jednakże autonomii towarzyszyły surowe ograniczenia finansowe - systematyczne finansowe zaciskanie pasa było przez całe lata 90. najbardziej charakterystyczną cechą akademickiej produkcji wiedzy w Europie Środkowej, a jego wpływ na systemy szkolnictwa wyższego, instytucje akademickie i indywidualnych badaczy jest jeszcze dzisiaj nie do przecenienia. Ciągle żyjemy w cieniu tamtych lat, zarówno instytucjonalnie, jak i indywidualnie. Między 1990 a 2005 r. pojawiło się w Polsce kilkanaście projektów ustaw o szkolnictwie wyższym, ale uchwalone zostały tylko dwie: ustawa z 1990 r., wprowadzająca autonomię instytucjonalną, wolność akademicką w badaniach i akademicką kolegialność w zarządzaniu, oraz ustawa z 2005 r., przystosowująca polskie uczelnie do wymagań procesu bolońskiego.

Reformy z lat 2009-2011 wprowadzily nowe zasady gry akademickiej - po raz pierwszy państwo stało się oddzielnym, potężnym interesariuszem, mającym decydujący głos w sprawach polityki szkolnictwa wyższego. Dodatkowo, również po raz pierwszy, głos państwa jako interesariusza wyraźnie różnił się od głosu wspólnoty akademickiej (lub jej części) reprezentowanej przez KRASP. Dwa paradygmaty myślenia o przyszłości szkolnictwa wyższego po raz pierwszy zostały ze sobą publicznie skonfrontowane. Polskie szkolnictwo wyższe wciąż funkcjonuje zgodnie z tradycyjnymi, humboldtowskimi i, w dużej mierze, komunistycznymi zasadami gry - zasadami stylizowanej wizji uniwersytetu Johana P. Olsena (2007: 29-31) jako „rządzącej się zasadami wspólnoty badaczy” oraz instytucji opartej na tradycyjnych wartościach akademickich, w stopniu niemającym swojego odpowiednika w większości systemów szkolnictwa wyższego Europy Zachodniej. Podczas gdy $\mathrm{w}$ tych ostatnich współwystępowanie różnych stylizowanych wizji uniwersytetu jest zjawiskiem dominującym, w Polsce ostatni pakiet reform zamierzał zastąpić 
tradycyjną perspektywę, zmienioną jedynie nieznacznie po 1989 r., wizją uniwersytetu jako „narzędzia realizacji krajowych celów politycznych” (Olsen 2007: 31), w tym celów gospodarczych. Przesunięcie w myśleniu o polityce szkolnictwa wyższego, które dokonało się w Polsce, pokazuje wyraźnie nowy kierunek zmian - znane z systemów zachodnioeuropejskich odchodzenie od modelu humboldtowskiej „,republiki uczonych” w stronę modelu, w którym radykalnie wzrasta rola otoczenia zewnętrznego uniwersytetu (Kwiek 2012). Jak wszędzie w systemach masowych, nowy paradygmat zaczyna wypierać paradygmat stary, co powoduje ogromne napięcia instytucjonalne związane z koniecznością stopniowego redefiniowania akademickiej kultury organizacyjnej od bardziej kolegialnej do bardziej menedżerskiej - pojawiają się plany strategiczne, strategiczne cele i instytucjonalne strategie.

Reformy z lat 2009-2011 były możliwe z dwóch powodów: niespotykanej uprzednio determinacji reformatorów i równie niespotykanego wcześniej, powszechnego społecznego przekonania o tym, że system jest nieefektywny (Bolecki i Żylicz 2007; Białecki 2008; Jajszczyk 2009; Kędzierski 2009; Leja 2008). Korekta systemu w postaci reform minister Barbary Kudryckiej (zwanych dalej reformami Kudryckiej) doprowadziła do chwilowej poprawy jego społecznych notowań, a tym samym szanse na radykalne zmiany na jakiś czas zmniejszyły się, zgodnie z zasadami znanymi z badań organizacji (Żylicz 2012; Jajszczyk 2013; Brzeziński 2014). Radykalne zmiany są bowiem najczęściej możliwe w systemach (i organizacjach), które powszechnie uznaje się za chylące się ku upadkowi. Uzasadnieniem reform staje się wtedy zapobieżenie katastrofie, czemu towarzyszy silne poparcie społeczne lub silne poparcie wewnątrz organizacji. W ostatnich dwóch latach przekonanie o nieefektywności systemu znowu rośnie, podobnie jak poparcie społeczne dla dalszych reform sektora akademickiego - tym samym rośnie motywacja decydentów do przeprowadzania dalszych reform (MNISW 2015; Górniak 2015a; 2015b; Izdebski 2015; Jurek 2015; Marciniak 2016; Morawski 2015; Wilkin 2015; Woźnicki 2015; Wolszczak-Derlacz 2015; Muszewska i in. 2015; OPI 2016; Sułkowski 2016). Pomagają im w tym szeroko analizowane międzynarodowe dane porównawcze, które pokazują, że świat polskiej akademii coraz bardziej oddala się od świata zachodniego (pomijając wyjątki, również szeroko opisywane w tym tomie przykłady ogromnych sukcesów międzynarodowych: Wydział Matematyki, Informatyki i Mechaniki Uniwersytetu Warszawskiego w ujęciu Stefana Jackowskiego i Międzynarodowy Instytut Biologii Molekularnej i Komórkowej w ujęciu Jacka Kuźnickiego i Janusza M. Bujnickiego). Nowe negatywne impulsy zawsze rodzą silniejszą motywację u reformatorów. Z przekonania, że tak dalej być nie może, ponieważ społeczne i gospodarcze koszty rosnącej izolacji polskiej nauki w świecie oraz izolacji od otoczenia zewnętrznego w Polsce są zbyt wysokie, zrodziło się myślenie o konieczności głębszych reform: paliwo dostarczane przez reformy Kudryckiej przestało wystarczać (Żylicz 2015). 
Rząd pod koniec poprzedniej dekady przygotował pakiet (w założeniu) radykalnych zmian i poddał je pod publiczną dyskusję. Po raz pierwszy po 1989 r. nowi interesariusze szkolnictwa wyższego - a nie tylko kadra akademicka i jej reprezentanci - zostali jasno określeni i zapytani o oficjalne poglądy na temat pakietu reform. Poglądy te, jak miało się okazać, były znacząco odmienne od poglądów wspólnoty akademickiej. Do grona interesariuszy zaangażowanych w długi proces konsultacji społecznych włączono w szczególności studentów - a pośrednio ich rodziców - i ich organizacje, doktorantów i ich organizacje, a także pracodawców za pośrednictwem zrzeszających ich stowarzyszeń. Poszukując wsparcia, reformatorzy z lat 2009-2011 zwrócili się bezpośrednio do nowych grup interesariuszy i pokazywali długoterminowych wygranych reform (zgodnie z wzorcami znanymi z ekonomii politycznej reform OECD; Høj i in. 2006; OECD 2010; Dąbrowa-Szefler 2009). Sprzeciwowi wspólnoty akademickiej wobec głównych części pakietu reform Kudryckiej towarzyszyło stosunkowo duże wsparcie ze strony owych nowych interesariuszy. Poddawane pod publiczną dyskusję kolejne oficjalne „założenia reformy", prezentowane w różnych formach w okresie 2009-2010, podkreślały instrumentalny charakter oczekiwanych zmian i oznaczały de facto koniec dominacji tradycyjnego postrzegania uniwersytetu jako wyizolowanej ze społeczeństwa i gospodarki wspólnoty badaczy oraz kres tradycyjnej symbiozy na poziomie ministerialnym między politycznymi decydentami a rektorami najlepszych publicznych uniwersytetów.

Reformy Kudryckiej stanowiły pierwszą odpowiedź na kumulujące się od dwóch dekad problemy strukturalne. Odzyskana w 1990 r. instytucjonalna autonomia i instytucjonalna demokracja wyrażająca się w skrajnej, rozbudowanej kolegialności akademickiej oznaczały, że systematyczne przekształcanie uczelni, koordynacja oferowanych na zasadach rynkowych (czy quasi-rynkowych) obszarów studiów niestacjonarnych czy racjonalizacja uczelnianych wydatków stały się na wiele lat niemożliwe. Skrajnie demokratyczne formy zarządzania sprawiały również, że okresowa ocena jakości prowadzonych instytucjonalnie i indywidualnie badań naukowych była coraz trudniejsza. Jednocześnie - co miało ogromny negatywny, demotywujący wpływ na całą profesję akademicką - mniej lub bardziej bolesne pozbycie się słabej kadry akademickiej, niezdolnej do spełniania choćby podstawowych wymogów misji badawczej na najlepszych uczelniach, stało się niemożliwe.

Odpowiedź reformatorów z lat 2009-2011 na powyższe problemy strukturalne to z jednej strony stworzenie Komitetu Ewaluacji Jednostek Naukowych (KEJN), a z drugiej - Narodowego Centrum Nauki (NCN). Jednak po kilku latach funkcjonowania obydwu instytucji ujawniły się ich ograniczenia: bezsilność parametryzacji i kategoryzacji w spełnianiu zadania podnoszenia jakości badań naukowych (Antonowicz i Brzeziński 2013; Brzeziński 2015; Kulczycki 2017) i znaczącego różnicowania środków na badania oraz niedofinansowanie najważniejszej instytucji 
finansującej badania (któremu towarzyszy spadek nakładów na badania statutowe). Nierozwiązany został problem wyłaniania uczelni badawczych i ich dodatkowego finansowania, a szerzej - problem braku pionowej stratyfikacji w systemie. Nie udała się też reforma systemu stopni naukowych i systemu awansowego - wyraźnie spadł średni poziom habilitacji i profesury tytularnej i nie doszło do prognozowanego wzrostu umiędzynarodowienia badań naukowych. Klęską okazał się też udział Polski w systemie grantowym European Research Council (ERC). Presja na kolejne reformy rosła w sposób nieunikniony, zwłaszcza w obliczu bezpośredniej konfrontacji tysięcy polskich badaczy z systemami zachodnimi w ramach rosnącego umiędzynarodowienia polskiej nauki, również ze środków NCN.

\section{Nowy kontrakt społeczny państwo - akademia w Europie: kres bezwarunkowego rozwoju nauki}

Nauka akademicka w Europie kontynentalnej jest ściśle związana z uniwersytetami publicznymi, a co za tym idzie - ze stałym publicznym finansowaniem. Uzasadnienie finansowania zmieniało się w ostatnich trzech dekadach, podobnie jak rewizji ulegał powojenny „kontrakt społeczny” obowiązujący między państwem a uniwersytetami, najlepiej wyrażony w amerykańskim raporcie Vannevara Busha o nauce jako endless frontier (Bush 1945). Ben Martin i Henry Etzkowitz (2000: 7) podsumowali ów nowy, wyłaniający się właśnie kontrakt społeczny następująco: „istnieje wyraźne oczekiwanie, że w zamian za finansowanie ze środków publicznych naukowcy i uniwersytety muszą uwzględniać potrzeby »użytkowników« funkcjonujących w gospodarce i społeczeństwie”. To właśnie inaczej wyrażona idea rosnącej roli interesariuszy zewnętrznych uczelni - kosztujące coraz więcej masowe systemy szkolnictwa wyższego muszą się coraz szerzej otwierać na świat zewnętrzny; gospodarka i społeczeństwo w systemach elitarnych, w tym w elitarnym systemie komunistycznym w Polsce, nie były istotnym punktem odniesienia (Antonowicz 2016; Kwiek 2016a). Dzisiaj w całej Europie rządy redefiniują swoje stosunki z sektorem akademickim i czynią to tym silniej, im większe środki na niego przeznaczają.

Jednak zasady nowego kontraktu państwa z uniwersytetami (i całym różnicującym się sektorem szkolnictwa wyższego) mogą się coraz bardziej różnić dla odmiennych obszarów badawczych, ponieważ w ostatnich kilku dekadach w coraz większym stopniu ,jedynymi argumentami, które obecnie mają jakiekolwiek znaczenie dla rozwoju nauki, są te, które odwołują się do składanej przez nią obietnicy przyszłego bogactwa i innych namacalnych korzyści” (Ziman 1994: 85). Gospodarka oparta na wiedzy sprawia, że niektóre typy produkowanej przez uniwersytet wiedzy (np. to, co Gareth Williams określa mianem „wiedzy gospodarczo użytecznej” czy „gospodarczo wartościowej wiedzy skodyfikowanej”, Williams 2012: 20, 
34; por. Brown, Lauder i Ashton 2011) okazują się istotniejsze - i łatwiejsze do sfinansowania - niż inne. Rozwój nauki, a co za tym idzie - możliwości zatrudniania młodej kadry, może wyglądać różnie w odmiennych obszarach badań na różnych wydziałach uniwersytetów.

Ekspansji w niektórych obszarach szkolnictwa wyższego i uniwersyteckiej nauki może towarzyszyć kurczenie się innych obszarów. Jedne wydziały mogą rosnąć, a inne się kurczyć - z powodów czysto finansowych. Geografia obszarów badań, a w konsekwencji również geografia dostępnych posad akademickich, stopniowo ewoluuje. W niektórych krajach ewolucja ta jest coraz silniej determinowana przez krajowe strategie rozwoju szkolnictwa wyższego i innowacji oraz przez nowe, bardziej „konkurencyjne” reżimy finansowania badań, którym towarzyszy nowa, bardziej selektywna polityka naukowa (Geuna 1999).

Gospodarka wiedzy zmienia również stopniowo profil wyborów studenckich w szkolnictwie wyższym, gdyż premia płacowa za wyższe wykształcenie w coraz większym stopniu jest powiązana z dziedzinami nauki i dziedzinami ukończonych studiów (a napięcie między uniwersytetem jako dobrem wspólnym a uniwersytetem dostarczającym dobra prywatne staje się coraz większe; por. Szadkowski 2015; 2017). Wpływ rosnącej liczby dowodów na to, że „nie wszyscy absolwenci są w równym stopniu chętnie poszukiwani przez pracodawców po to, by wnosić swój wkład do gospodarki wiedzy" (Williams 2012: 33), na przyszłość różnicowania się profesji akademickiej (według dyscyplin naukowych) jest wciąż niejasny. Wiemy tylko, że jeśli w pewnych obszarach nauki nie będzie studentów, to może się z czasem okazać, że obszary te w ramach uniwersytetów mogą w nieodwracalny sposób zamierać, ponieważ staną się niefinansowalne (np. część humanistyki i nauk społecznych może zniknąć w przypadku wprowadzenia opłat za studia w tych obszarach). To ogromne zagrożenie dla spójności instytucji uniwersytetu i dla badań podstawowych jako całości, a procesy te widać najlepiej w krajach anglosaskich.

Ujmowana w bardzo szerokich kategoriach historia nauki była do tej pory historią intensywnego rozwoju: „skala wszystkich działań naukowych i technologicznych nieustannie się rozszerzała. Każda miara uchwytująca te działania - liczba zaangażowanych ludzi, ilość wykorzystywanych zasobów, liczba opublikowanych artykułów i zgłoszonych patentów, wpływ komercyjny i przemysłowy itd. - wydawała się rosnąć w postępie geometrycznym przez najlepszą część ostatnich trzech stuleci” (Ziman 1994: 67). Jednak taka historia rozwoju nauki może okazać się zjawiskiem wyjątkowym. Rozwój nauki był powiązany z liczbową ekspansją uniwersytetów oraz liczbową ekspansją dostępnych etatów akademickich na uniwersytetach w całej Europie: jednak od dwóch dekad przestajemy myśleć o ekspansji i koncentrujemy się na utrzymaniu stanu posiadania.

Tradycyjny kontrakt społeczny państwa z akademią, upraszczając, oznaczał spory zakres wolności akademickiej, dużą wolność dysponowania własnym czasem, dużą stabilność zawodową i - z coraz większym trudem, ale jednak możliwy 
do utrzymania - materialny status klasy średniej przynajmniej dla uniwersyteckiej profesury. Nowy kontrakt oznacza stopniowe wycofywanie się państwa ze wszystkich gwarantowanych dotąd, głównie w niepisany sposób, wymiarów pracy akademickiej: malejącą wolność akademicką (w sensie rosnącego nacisku na stosowalny, a nie podstawowy charakter badań, a więc na naturę relacji przedmiot badań - jego publiczne finansowanie), mniejszą stabilność zawodową, malejącą władzę dysponowania własnym czasem i relatywnie spadający (w stosunku do jedynej kategorii porównawczej: profesjonalistów) status materialny.

Tradycyjne motywy prowadzenia badań akademickich - triada curiosity, ribbon i gold, czyli naukowa ciekawość, akademickie zaszczyty i sfera materialna (Stephan i Levin 1992; Stephan 2012; Lam 2011) - odgrywają dziś taką samą rolę jak w poprzednich dekadach, ale wszystkie, a zwłaszcza pierwszy i trzeci, podlegają zarazem systematycznym ograniczeniom (Kwiek 2017a).

\section{Permanentne adaptacje do ewoluującego otoczenia zewnętrznego: konsekwencje słabnącego zaufania społecznego}

Zmieniające się instytucjonalne, społeczne, gospodarcze, kulturowe i prawne otoczenie europejskich instytucji szkolnictwa wyższego coraz bardziej wymusza na instytucjach i ich jednostkach podstawowych (oraz kadrze akademickiej) funkcjonowanie $\mathrm{w}$ stanie permanentnej adaptacji. Instytucjonalne i indywidualne adaptacje akademickie powstają $\mathrm{w}$ odpowiedzi na zmiany zarówno w finansowaniu, jak i zarządzaniu. Jak wspominaliśmy, reformowanie instytucji uniwersytetów nie prowadzi jednak do ich zreformowania. W kategoriach najbardziej ogólnych ustawodawcy europejscy (w ramach Nowego Zarządzania Publicznego; por. Czarnecki 2013) mają tendencję do postrzegania uniwersytetów - podobnie jak innych instytucji publicznych - jako „niekompletnych”, a reformy mają na celu uczynienie z nich „kompletnych” instytucji (Brunsson 2009). Reformowanie prowadzi zatem zawsze do kolejnych fal reform (Maassen i Olsen 2007).

Naukowcy muszą się nieustannie dostosowywać do zmieniających się instytucji, które z kolei dostosowują się do permanentnie ewoluującego otoczenia zewnętrznego (w Polsce choćby do wymogów KEJN i NCN: niedostosowanie oznacza ogromne i rosnące w czasie straty finansowe i prestiżowe). Zmiany w globalnym dyskursie dotyczącym roli uniwersytetów zmieniają punkty odniesienia w dyskursach krajowych (w Polsce było to widać po inspirującej dla poprzedniej fali reform roli raportu OECD na temat naszych uczelni z 2007 r.), a zmieniające się otoczenie zewnętrzne zmienia również funkcjonowanie uczelni na mikropoziomie kadry akademickiej (Kwiek 2015b). Najszybciej zmienia się myślenie młodej kadry - o czym piszemy w części poświęconej rosnącym napięciom międzypokoleniowym. 
Nowym kontekstem, w którym funkcjonują uniwersytety europejskie, jest także niestabilne zaufanie społeczne do wszelkich instytucji publicznych. Zaufanie to nie jest (niejako automatycznie, jak jeszcze dwie czy trzy dekady temu) gwarantowane, co oznacza poważną zmianę przeważających w powojennej Europie nastrojów społecznych. To z tym zaufaniem związane było hojne finansowanie publiczne i (uważany za oczywisty) wysoki prestiż społeczny uniwersytetów i kadry akademickiej, a przynajmniej jej najwyższych segmentów, czyli profesury. Kruchość akademickiego status quo jest dziś powszechnie diagnozowana w Europie. Dominuje poczucie kolejnych nadciągających zmian, mimo że aktualne zmiany już są odczuwane jako silnie zmieniające reguły gry akademickiej.

W sytuacji obecnie wprowadzanych w życie reform w Europie mamy do czynienia $\mathrm{z}$ dynamiką zmian zachodzących w stosunkach między państwem (tradycyjnie głównym sponsorem procesów kształcenia i akademickich badań naukowych) a naukowcami zatrudnionymi w sektorze szkolnictwa wyższego (tradycyjnie głównymi beneficjentami państwowego sponsorowania całego krajowego przedsięwzięcia akademickiego). Kadra akademicka tradycyjnie miała do odegrania rolę powierniczą. Konstytutywne reguły, normy i praktyki akademickie nie dają się latwo zmieniać i aby je zakorzenić w akademickich strukturach, potrzeba czasu, podobnie jak potrzeba czasu, by je zmienić. Szczególnie starsza kadra akademicka często postrzega siebie jako depozytariuszy tradycyjnych akademickich regul, norm i praktyk; młodsza kadra, chociaż zna tradycyjne reguły, normy i praktyki w postaci przekazu od swoich starszych kolegów, musi jednak grać według zredefiniowanych zasad, jeśli chce z powodzeniem podejmować dalsze kroki we własnych karierach naukowych. Istnieje tym samym realna możliwość rozchodzenia się świata tradycyjnej akademii - w którym funkcjonują starsze i najstarsze pokolenia naukowców - i od nowa projektowanego świata akademii, którym rządzą adaptowane do lokalnych warunków globalne zasady funkcjonowania nauki i adaptowane do sektora akademickiego zasady znane z europejskiego sektora publicznego.

\section{Od epoki zawieszenia tradycyjnych norm akademickich do epoki powstrzymywania utraty aspiracji badawczych}

Rozwój nauki po upadku systemu komunistycznego był istotnie hamowany z zewnątrz przez niski poziom finansowania, ale w nie mniejszym stopniu był hamowany od środka - uniwersalne zasady decydujące o rozwoju nauki akademickiej zostały niemal powszechnie zawieszone. Nie byli przyjmowani do pracy i awansowani tylko najlepsi naukowcy - system tolerował, a często również awansował wszystkich, demotywując tym samym tych, którzy chcieliby funkcjonować według uniwersalnych zasad nauki znanych z systemów zachodnich. Ludzkie oblicze polskich uczelni po $1989 \mathrm{r}$. zrodziło ich oblicze nienaukowe - nawet najlepsze uczelnie 
były traktowane jak chronione miejsca pracy, z których odchodzenie z racji niestosowania się do uniwersalistycznych reguł nauki obejmujących przede wszystkim publikowanie (Merton 1968; Ziman 1994) miałoby być bezdusznym „zwolnieniem z pracy”. Charakter najlepszych uczelni jako zwykłych miejsc pracy, a nie obwarowanych uniwersalnymi zasadami miejsc pracy naukowej, praktycznie stopniowo, coraz bardziej skutecznie, odcinał polską naukę od nauki globalnej.

Globalny system nauki jest bezlitosny - i bezlitośnie kumulatywny. Kumulują się narodowe sukcesy, ale kumulują się i narodowe niepowodzenia. Z szerszej perspektywy obejmującej to, co polska nauka osiągnęła w kontekście tego, co mogła osiągnąć - pierwsze dwie dekady po 1989 r. to czas stracony. Niestety kumulatywność nauki powoduje, że wpływu reform Kudryckiej na powszechne postrzeganie polskiej nauki jako całości w Europie nie będzie widać jeszcze przez wiele lat, nawet przy zwiększonych nakładach na badania. Podobnie będzie rzecz jasna z reformami w ramach Ustawy 2.0. Wpływ zmian z lat 90. w ramach kultury instytucjonalnej jest wciąż silnie odczuwany, a normy akademickie okresu komunistycznego - paradoksalnie bardziej uniwersalistyczne niż normy obowiązujące po upadku komunizmu - nie uchroniły najlepszych polskich uczelni przed niską produkcją wiedzy w latach 90. i przed procesami, które nazwaliśmy „deinstytucjonalizacją” misji badawczej polskich uniwersytetów (Kwiek 2012). Reformy zawsze otwierają szanse na odnowę kultury akademickiej, rewizję tych reguł, norm i praktyk akademickich, które doprowadziły do dzisiejszej zapaści nauki (jako jedne z najważniejszych czynników), ale reinstytucjonalizacja misji badawczej na najlepszych uniwersytetach publicznych, szczególnie w miękkich obszarach nauki, będzie procesem trudnym, długotrwałym i kosztownym.

W okresie postkomunistycznej ekspansji z lat 1990-2005 (bo lata 2006-2017 to już epoka kurczenia się systemu; por. Kwiek 2013; 2016b; Białecki i Dąbrowa-Szefler 2009; Siemińska i Walczak 2012) uniwersytety publiczne stawały się w coraz większym stopniu instytucjami wewnętrznie podzielonymi: uznającymi odmienne zasady akademickiej gry, tworzącymi odmienne kultury instytucjonalne i wewnętrzne, redefiniującymi normy akademickie i angażującymi się w odmienne misje akademickie, zarówno na poziomie wydziałowym, jak i indywidualnym. Najważniejsza linia podziału biegła między dziedzinami twardymi i miękkimi, a pośrednio między dziedzinami oferującymi możliwość dodatkowego kształcenia (w obu sektorach: prywatnym i publicznym) i pozostałymi.

Upadek komunizmu i wyłonienie się sektora prywatnego (połączone z deprymująco niskimi płacami w publicznym szkolnictwie wyższym) sprawiły, że tradycyjne akademickie reguły i normy konstytuujące prestiżowe uniwersytety przestały być uważane za naturalne. Okres ekspansji spowodował stopniową deinstytucjonalizację (czyli instytucjonalną dewaloryzację) misji badawczej, a wraz z nią pojawiła się niepewność co do tego, które zachowania akademickie są uzasadnione i co jest rdzeniem akademickiej tożsamości na najlepszych uniwersytetach. Jedną 
z głównych konsekwencji rozwoju sektora prywatnego w latach 1995-2005 była ograniczona presja akademicka na reformowanie uniwersytetów, w tym na zwiększanie poziomu płac akademickich. Płace w tym okresie były niskie, więc posiadanie dodatkowego miejsca zatrudnienia traktowano powszechnie jako rozsądną i akceptowalną strategię przetrwania wspólnoty akademickiej.

Brane za pewnik normy akademickie dominujące na europejskich uniwersytetach badawczych pozostawały w zawieszeniu w miękkich dziedzinach akademickich przez 10-15 lat transformacji systemu. Tradycyjna „logika stosowności” (March i Olsen 2006) w tych segmentach prestiżowych uniwersytetów była słaba i niezdolna do powstrzymania przekierowania indywidualnej i instytucjonalnej energii w stronę dodatkowego płatnego kształcenia, szczególnie w sektorze prywatnym. W okresie ekspansji edukacyjnej powstawały rozmaite publiczne usprawiedliwienia i uzasadnienia akademickiego wielozatrudnienia, np. ideologia „synergii” obu sektorów, „zdrowej, rynkowej konkurencji” i zawsze pożytecznej, międzysektorowej „wymiany doświadczeń”. Przede wszystkim jednak polskie uczelnie zostały w ramach nowej ideologii akademickiej wyjęte z kontekstu europejskiego - miały być w jej ramach unikalne w skali europejskiej i nieporównywalne z uczelniami zachodnimi. Po raz pierwszy porównania na podstawie międzynarodowych danych zostały zastosowane w przygotowaniach do reform z lat 2009-2011, co samo w sobie uważano za podejście podejrzane.

Tymczasowe (z perspektywy historycznej) zawieszenie tradycyjnych reguł i norm akademickich w najlepszych krajowych instytucjach wysoko wartościujących działania badawcze oraz (tymczasowa) akceptacja nowych sposobów zachowań akademickich przyczyniły się, z jednej strony, do ogromnego rozwoju sektora prywatnego, a z drugiej przyczyniły się do istotnego regresu dokonań naukowych i utraty aspiracji badawczych, w tym aspiracji międzynarodowych, szczególnie przez kadrę w miękkich dziedzinach nauki. Spadek aspiracji badawczych części wspólnoty akademickiej w latach 90. doprowadził więc pośrednio do obniżenia poziomu finansowania badań - kadra okazała się słabą i silnie podzieloną grupą interesu, niezdolną do konsekwentnego stawiania żądań dotyczących wyższego finansowania badań naukowych i wyższych płac. Do tego niezdolną do promowania sensownej wizji reform sektora akademickiego. Jednym z wyjaśnień permanentnego niedofinansowania badań naukowych w Polsce jest skupienie się sektora uniwersyteckiego na kształceniu na wielką skalę oraz brak presji ze strony kadry, szczególnie presji zorganizowanej, na podnoszenie publicznych nakładów na badania.

Nowe zasady funkcjonowania uczelni, wprowadzone po 1989 r. w wersji nieznanej już w tym czasie w Europie Zachodniej, dające ogromną wolność i kadrze akademickiej, i akademickim instytucjom, prowadziły stopniowo do erozji tradycyjnych zasad w większej części najlepszych polskich uniwersytetów oraz do kwestionowania ustanowionych praktyk organizacyjnych w tych obszarach, w któ- 
rych obserwowano wielką ekspansję ilościową systemu. W latach 9o. i częściowo w pierwszej dekadzie XXI wieku została zaburzona równowaga między kształceniem a badaniami w dziedzinach miękkich, co prowadziło do dewaloryzacji roli aktywności badawczej. Reformy z lat 2009-2011 aktywność tę reinstytucjonalizowały, po raz pierwszy wprowadzając ścisły, często mierzalny, związek między wynikami badań - na poziomie indywidualnym i instytucjonalnym (zhierarchizowane pod względem wagi obiegu naukowego publikacje, uzyskiwane w trybie konkurencyjnym granty badawcze - ujmowane szczegółowo w parametryzacji jednostek naukowych) - a ich finansowaniem. Po raz pierwszy państwo stało się w ten sposób samodzielnym aktorem i rzeczywistym interesariuszem szkolnictwa wyższego, który jeszcze do niedawna miał wobec uczelni i uczonych wymagania jedynie formalne.

\section{Długoterminowe konsekwencje deinstytucjonalizacji badawczej misji uniwersytetów w okresie ekspansji edukacyjnej}

Polskie uniwersytety po 1989 r. znalazły się w tymczasowej normatywnej próżni - niespodziewanie musiały się zmierzyć z wielkimi i wcześniej nieznanymi wyzwaniami organizacyjnymi i finansowymi, nie mając żadnych wskazówek dotyczących tego, jak powinny w nowej sytuacji postępować. W latach 90. w szkolnictwie wyższym nie istniała czytelna krajowa polityka edukacyjna czy jasna strategia narodowa w obszarze szkolnictwa wyższego. Odziedziczone akademickie normy i zachowania, wzorce myślenia i działania, instytucjonalne procedury, praktyki i etos akademicki okazywały się jedynie częściowo użyteczne w ramach rodzących się instytucjonalnych strategii przetrwania. Trzymanie się tradycyjnych, odziedziczonych po okresie komunistycznym zasad nie sprawdzało się, ponieważ zasady te uważano powszechnie za przestarzałe, a ponadto autorytarne i antydemokratyczne.

Zewnętrzny szok związany z transformacjami w gospodarce oraz z finansową polityką zaciskania pasa przez całe lata 90. ukształtował dynamikę zmiany instytucjonalnej. Uniwersytety orientowały się instytucjonalnie na zjawiska związane z ekspansją ilościową i odpowiadały na drastyczne niedofinansowanie w sposób, którego oczekiwałyby od nich tradycyjne modele zasobowe w teorii organizacji poszukiwały sposobów na przetrwanie we wzajemnym procesie interakcji między organizacjami a otoczeniem (Pfeffer i Salancik 2003: 258-262), zarówno na mikropoziomie kadry akademickiej, jak i na mezopoziomie instytucji.

Tradycyjne zasady i normy akademickie obowiązujące na najlepszych uniwersytetach publicznych, według których badania naukowe mają istotne znaczenie dla całego przedsięwzięcia akademickiego, przez całe lata 9o. były stopniowo osłabiane. Traciły na znaczeniu, były szeroko kwestionowane i podawane w wątpliwość, 
tracily swoją silę oddziaływania. Dobre polskie uniwersytety stawały się w tych latach - ale również w kolejnej dekadzie - instytucjami, które miały coraz mniej wspólnego z dobrymi uniwersytetami funkcjonującymi w świecie zachodnim.

Doskonałym mechanizmem obronnym, który wypracowała sobie w latach 90. kadra akademicka, było upowszechniane przekonanie o wyjątkowości polskich uniwersytetów w kontekście uniwersytetów w świecie zachodnim (do którego jednocześnie społeczeństwo polskie aspirowało). Polski rynek szkolnictwa wyższego i akademicki rynek pracy były całkowicie zabetonowane - przekonania wpływowej mniejszości, korzystającej z pasożytniczej symbiozy z sektorem prywatnym, zdominowały publicznie prezentowane przekonania całej wspólnoty akademickiej. Wspomniane procesy występowały szczególnie w obszarach akademickich objętych najsilniejszą ekspansją edukacyjną. Cena, jaką za procesy osłabiania tradycyjnych zasad akademickich w miękkich dziedzinach zapłaciły - i nadal płacą, ponieważ kultura instytucjonalna i kultura akademicka zmieniają się długo - wszystkie najlepsze uniwersytety publiczne, była bardzo wysoka. Instytucjonalna koncentracja na misji dydaktycznej, kosztem misji badawczej, stała się zasadniczym problemem, z którym musiały się zmierzyć reformy Kudryckiej. Jednak dziedzictwo lat 1990-2010 jeszcze długo będzie wywierało negatywny wpływ na funkcjonowanie publicznego szkolnictwa wyższego, zwłaszcza na uprawianie badań naukowych i poziom jego publicznego finansowania. Uniwersytety utraciły część publicznego zaufania, społecznego prestiżu - a tym samym wypadły z kręgu krajowych priorytetów; dlatego renegocjacje relacji uniwersytetów z państwem będą trudniejsze, a dostęp do publicznego finansowania nauki na poziomie możliwym jeszcze dekadę temu - obwarowany wieloma nowymi warunkami, z którymi trzeba będzie się pogodzić.

\section{Nowe napięcia międzypokoleniowe i rosnące rozwarstwienie kadry akademickiej: „lokalnośćc i „globalnośćc w nauce}

Polskie uczelnie cechuje zróżnicowanie międzypokoleniowe, diagnozowane na podstawie rozległych badań empirycznych (Kwiek 2015a; 2017b). Szczegółowe badania pokazują, że młodsza kadra coraz częściej pracuje w odmienny sposób i w odmienny sposób myśli o swojej pracy (akademickiej) niż kadra starsza. Młodsza kadra zatrudniona na uniwersytetach pokładała wielkie nadzieje w reformach Kudryckiej - chociaż zarazem dostrzegała ich pokoleniową niesprawiedliwość. Powszechnie uważała, że reformy finansowania badań naukowych i wymogów stawianych w procesie awansu naukowego w praktyce mają wyłączne zastosowanie do młodszego pokolenia - starsze pokolenie projektuje nowe zasady, których jednak nie stosuje do siebie. 
Młodzi naukowcy coraz częściej uważają, że ich badania mają znaczenie wyłącznie wtedy, kiedy aspirują do przynależności do międzynarodowej dyskusji naukowej, natomiast dla badaczy „lokalnych” punktem odniesienia jest nauka uprawiana w Polsce. Napięcie między tym, co kosmopolityczne, a tym, co lokalne (pokazane po raz pierwszy przez Alvina Gouldnera, 1957) odnosi się do sposobu pojmowania zarówno nauki, jak i aktywności badawczej. Napięcie to odwołuje się do naturalnych grup odniesienia dla naukowców w prowadzonych przez nich badaniach, do preferowanych - i oczekiwanych przez najbliższe otoczenie instytucjonalne - kanałów publikacji, rodzajów konferencji naukowych czy typów standardowo czytanych książek i czasopism naukowych. We wszystkich grupach wiekowych udział badaczy „lokalnych” jest znaczący.

Poczucie intelektualnego komfortu zapewniane przez zamknięte (zarówno fizycznie, jak i naukowo) granice dla większości polskich naukowców pracujących $\mathrm{w}$ warunkach komunizmu zniknęło dziś na zawsze. Pytanie o znaczenie w nauce światowej i o to, czy wyniki prowadzonych badań mogą być interesujące w międzynarodowym obiegu naukowym, jest nowym, nieznanym dotąd pokoleniowym doświadczeniem. Świat nauki stał się globalny, a ponadprzeciętna z porównawczej perspektywy europejskiej i ciągle dominująca „lokalność” naszej nauki (pokazana w wielu wymiarach empirycznie na próbie $N=3704$; Kwiek 2015c) z pewnością będzie się zmniejszać.

Problem pokoleniowości kadry jest problemem niedocenianym w polityce zatrudnienia. Różne kohorty młodych absolwentów uniwersyteckich oceniają atrakcyjność kariery akademickiej, porównując ją z innymi dostępnymi w danym momencie historycznym ścieżkami kariery zawodowej. Dlatego niektóre akademickie kohorty czy pokolenia - osoby faktycznie zatrudnione na uczelniach - mogą rekrutować się z najlepszych studentów i najlepszych doktorantów i doktorów, podczas gdy inne już tylko ze średnich. „Względna atrakcyjność karier w nauce zmienia się z biegiem czasu - wraz z nim zmieniają się też struktury możliwości zawodowych" (Stephan i Levin 1992: 117).

Dla kadry akademickiej okresu komunistycznego punktem odniesienia w nauce była przede wszystkim nauka krajowa, a międzynarodowy wymiar badań był najczęściej nieobecny - z powodów strukturalnych, ideologicznych i finansowych. Polityczna i gospodarcza integracja Polski z Europą Zachodnią oznacza radykalne zwiększanie roli naturalnych dla nauki światowej postaw kosmopolitycznych w nauce (i zmniejszanie roli naturalnych dla nauki peryferyjnej postaw lokalnych), szczególnie w przypadku młodszych pokoleń.

Oczekiwania formułowane pod adresem młodszych pokoleń kadry zatrudnionych w najlepszych ośrodkach są od czasów reform Kudryckiej coraz bardziej precyzyjnie formułowane - młodzi powinni publikować artykuły w prestiżowych czasopismach o wysokich współczynnikach wpływu i przynosić coraz więcej zewnętrznego finansowania badawczego, czyli zdobywać granty badawcze. Młodsze 
pokolenia naukowców akademicką zaściankowość czy badawczy prowincjonalizm darzą szczególną antypatią - a mogą sobie na to pozwolić niemal wyłącznie dzięki nowym, konkurencyjnym źródłom finansowania badań naukowych z NCN czy FNP i coraz szerszemu otwieraniu się na zachodni świat naukowy i jego konkurencyjne finansowanie. (Jedynym realnym i długoterminowym zagrożeniem dla rosnącej „globalności” polskiej nauki jest dziś polityka polityków, od której staramy się tu jednak abstrahować).

Rosną tym samym w polskiej akademii napięcia międzypokoleniowe, ponieważ to starsze pokolenia - jak wszędzie na świecie - podejmują decyzje dotyczące kariery akademickiej i awansów młodszych pokoleń. Subiektywność kryteriów, duża rola osobistych kontaktów, siła akademickich koterii w kontekście awansu naukowego mogą odstręczać od nauki. Jednym z marzeń młodych naukowców $\mathrm{w}$ specyficznym polskim kontekście instytucjonalnym, dawno zrealizowanym w systemach europejskich (Kwiek i Antonowicz 2015), jest marzenie o rządach merytokracji w nauce. A dojść do nich można tylko poprzez ewolucyjne reformy, w tym zrewidowaną politykę rekrutacyjną i awansową.

\section{Korekta polityki rekrutacyjnej i awansowej a przyszłość badań naukowych: liczą się ludzie, nie infrastruktura}

Polityka rekrutacyjna i polityka awansowa mają coraz większe znaczenie dla polskiego systemu, który jest dzisiaj znacznie mniej ukierunkowany badawczo, ale który pragnie doganiać bardziej radykalnie nastawione na badania naukowe systemy zachodnie (zob. analizę danych empirycznych w Kwiek 2015b). Odpowiedź na pytanie, kto jest zatrudniany, kto pozostaje na najlepszych uczelniach, a kto jest z nich zwalniany (oraz według jakich kryteriów), określi jakość nauki prowadzonej w Polsce i jej przyszłe miejsce w ujęciu międzynarodowym. Czy nowe pokolenia polskich naukowców w górnych warstwach zróżnicowanego pionowo systemu (bo przecież nie w ich dolnych, regionalnych i prowincjonalnych warstwach) mają być silnie zmotywowane do prowadzenia ambitnych badań naukowych, mocno zakorzenione w międzynarodowych sieciach badawczych, czy mają publikować przede wszystkim w prestiżowym obiegu międzynarodowym oraz czy mają być w dużym stopniu zaangażowane w międzynarodowe zmagania o akademicki prestiż i konkurencyjne finansowanie badań? W takim duchu przygotowaliśmy naszą wersję Ustawy 2.0 (Kwiek i in. 2016).

W dłuższej perspektywie, bez radykalnego podejścia do reform szkolnictwa wyższego, konkurencja między systemami zachodnioeuropejskimi, z młodymi naukowcami mocno nastawionymi na badania, a polskim systemem, z młodymi naukowcami o słabym nastawieniu na badania (oraz bardzo zaangażowanymi 
w dydaktykę) jest w praktyce niemożliwa. Przepaść w produkcji wiedzy między zachodnimi systemami a Polską, której wyrazem jest niski poziom produktywności badawczej, może wzrosnąć jeszcze bardziej, o ile nie zdefiniujemy, kogo chcemy zatrudniać w górnych warstwach zróżnicowanego systemu (a kogo z pewnością nie chcemy). Radykalna reforma musi prezentować praktyczną odpowiedź na tak postawione pytanie.

Musimy pamiętać, że suma pozornie drobnych decyzji zatrudnieniowych i awansowych podejmowanych na poziomie wydziałów (i zatwierdzanych niemal automatycznie na poziomie instytucjonalnym w ramach źle pojmowanej demokracji akademickiej i wydziałowej autonomii) powoduje nieuniknioną lawinę konsekwencji na poziomie systemu - konsekwencje to zmarnowane szanse i niewykorzystany potencjał. Polski system toleruje nietolerowalne, akceptuje nieakceptowane - od etapu oceny doktoratu, poprzez autonomiczne i nieodwoływalne przyznawanie habilitacji przez rady wydziałów (jeden z największych błędów systemowych reform Kudryckiej), po lokalne - zamiast międzynarodowych - wymogi stawiane i habilitacjom, i profesurom.

Niska produktywność polskiej nauki buduje od ponad ćwierćwiecza jej negatywny obraz w Europie i na świecie, co z kolei skutecznie odcina ją od współpracy międzynarodowej w badaniach naukowych i od międzynarodowych, przede wszystkich unijnych, konkurencyjnych środków na badania. Nie ma większego znaczenia jedno przyjęcie nieproduktywnego naukowo badacza do pracy i brak jednego zwolnienia takiego badacza na dobrej uczelni - ale ma fundamentalne znaczenie suma tysięcy tych decyzji podejmowanych w każdym roku w skali całego systemu przez ostatnich dwadzieścia lat. Odpowiedzialność za wieloletnie zaniedbania spada na całą samodzielną kadrę akademicką, bo to ona podejmuje autonomiczne decyzje $\mathrm{w}$ zdecentralizowanym, skrajnie kolegialnym systemie: mamy takich kolegów, jakich chcieliśmy mieć - i m.in. dlatego w ujęciu globalnym na takim poziomie mamy akademicką naukę (naukę w innych sektorach gospodarki tu pomijamy, ponieważ rządzi się ona innymi prawami).

\section{Dehermetyzacja nauki po 1989 r. i rewizja hierarchii wartości - konsekwencje otwarcia na globalną naukę}

A przecież zasady są stosunkowo proste. Świat nauki jest pod względem hierarchizacji niezwykle okrutny, ale zarazem merytokratyczny i otwarty (jak mało która instytucja społeczna). Hierarchia autorytetów „centrum” opiera się na miejscu zajmowanym w nauce światowej; natomiast hierarchia autorytetów naukowych „peryferii” jest rozmyta (Altbach 2002). Nawet słabe miejsce w międzynarodowym obiegu naukowym jest lepsze (dla kadry, ale i dla krajowej nauki i krajowych 
instytucji) niż żadne. Młode pokolenie jest tego coraz bardziej świadome. Sama świadomość możliwości funkcjonowania w międzynarodowym obiegu naukowym oraz rosnąca konieczność spełniania nowych, umiędzynarodowionych wymogów awansowych (o które konsekwentnie od lat zabiegamy) - całkowicie zmieniają reguły gry naukowej w Polsce. Przede wszystkim przez silne bodźce finansowe i konkurencyjność niewielkich środków na badania naukowe dostępnych z NCN (Kulczycki i in. 107; Kwiek 2016a).

Młoda kadra w Polsce jeszcze nie do końca rozumie mechanizmy rządzące nauką - wciąż w dużej mierze pozostaje na etapie konceptualizacji zachodzących od 2009 r. zmian przez pryzmat liczenia punktów za publikacje. Kolejny poziom konceptualizacji, ciągle rzadki, to powiązanie liczby punktów z prestiżem czasopisma. Rzecz przecież w nauce nie w punktach, a w prestiżu czasopisma, który jest bezpośrednio skorelowany z miejscem zajmowanym w globalnych kanałach dystrybucji wyników prowadzonych badań naukowych. Każda dziedzina nauki ma swoje najlepsze czasopisma i doskonale wiadomo, że dostęp do niech jest trudny, współczynnik sukcesu niski, a światowy poziom czytelnictwa wysoki. Doskonale również wiadomo, że nie ma na świecie autorytetów naukowych, które by nie publikowały na krótkiej liście czasopism najlepszych globalnie. Hierarchia w nauce opiera się w dużej mierze na funkcjonującej globalnie hierarchii czasopism naukowych, których działalność jest w całości oddana samym naukowcom poprzez rygorystyczny system peer review. Duża liczba punktów to w polskim przypadku - ciągle jeszcze za słabo konceptualizowany w ten sposób - zamiennik wysokiego prestiżu czasopisma.

Obecność w nauce światowej bierze się zatem niemal wyłącznie z obecności w najbardziej prestiżowym obiegu naukowym, który tworzą najlepsze - czyli najbardziej prestiżowe, a zarazem najbardziej niedostępne i selektywne - czasopisma. Obok nich funkcjonują globalne czy europejskie czasopisma mniej prestiżowe i mniej selektywne; następnie czasopisma zupełnie nieprestiżowe i nieselektywne. I wreszcie, w ogromnej większości, czasopisma polskie (część B wykazu czasopism naukowych MNiSW liczy 2209 pozycji: jedno czasopismo nieposiadające współczynnika wpływu przypada zatem w praktyce na 20-25 osób, przy założeniu, że około jedna trzecia kadry rotacyjnie w ciągu roku w ogóle nie publikuje prac naukowych).

Polska kadra akademicka również w tym sensie się rozwarstwia, że stwierdzenia dotyczące globalnego charakteru nauki nie dla wszystkich są zrozumiałe. Systematyczna dehermetyzacja polskiej nauki - czyli jej systemowe otwieranie na świat w aspekcie awansowym, finansowym, grantowym i publikacyjnym - równie systematycznie narusza stabilność dotychczasowych, najczęściej lokalnych hierarchii akademickich. Rosnąca pionowa stratyfikacja społeczna w nauce jest silnie skorelowana z umiędzynarodowieniem $\mathrm{w}$ badaniach naukowych (z jednym 
zastrzeżeniem: idealny model uprawiania nauki dotyczy przede wszystkim sektora uniwersyteckiego, uniwersytetów zlokalizowanych w zamożnych krajach zachodnich i przede wszystkim badań podstawowych).

Zachodzące w Polsce procesy dehermetyzacji nauki powodują nieznane przedtem napięcia, ponieważ otwarcie polskiej nauki na świat stopniowo podmywa tradycyjne hierarchie - pojawia się szerzej dotąd niedoceniany globalny wymiar nauki, stanowiący istotę funkcjonowania kadry akademickiej na najlepszych uniwersytetach europejskich. W sytuacji, w której rozhermetyzowana na Europe i świat nauka polska jest oceniana w kontekście osiągnięć globalnych, polska hierarchia naukowych autorytetów w sposób konieczny coraz silniej ewoluuje.

\section{Rozkład czasu pracy i orientacji akademickiej - praktyczny wymiar trudnej konkurencji z Zachodem}

W sensie praktycznym wiemy jedno: na polskich uniwersytetach nie powstanie konkurencyjna nauka, jeśli nasza kadra akademicka będzie poświęcać tak dużo czasu jak obecnie - w porównaniu z europejskimi kolegami - na kształcenie studentów. Rozwiązanie systemowe to rosnąca pionowa stratyfikacja systemu szkolnictwa wyższego, czyli jego - zaproponowane przez nas w ramach Ustawy 2.0 (Kwiek i in. 2016; Antonowicz i in. 2016) - silne zróżnicowanie uczelni pod względem funkcjonalnym. To z jednej strony najlepsze instytucje nastawione bardziej na badania niż na kształcenie, a z drugiej - pozostałe instytucje (czyli zdecydowana większość) nastawione bardziej na kształcenie. Pierwsze zatrudniające z czasem kadrę, która poświęca mniej czasu na kształcenie (ale więcej, z dobrymi, mierzalnymi wynikami, na badania), i drugie, w której stopniowo dystrybucja czasu pracy jest dokładnie odwrotna.

Takie zróżnicowanie systemu (choćby jedynie funkcjonalne, niekoniecznie formalne) pozwoliłoby skończyć z fikcją uprawiania nauki w miejscach, w których nauka skutecznie i konkurencyjnie uprawiana być nie może (z racji poziomu zasobów kadrowych i związanych z nim, coraz silniej w nowym systemie finansowania, zasobów finansowych). System musiałby być zarazem otwarty na mobilność kadry w obydwu kierunkach, a pierwszy typ instytucji (zwanych w świecie research universities) skupiałby z czasem niemal wyłącznie kadrę w sposób naturalny nastawioną na badania naukowe, a nie do nich przymuszaną przez system kolejnych stopni naukowych. Kadra nastawiona bardziej na kształcenie, niezbędna do funkcjonowania systemu jako całości i niezwykle cenna we wszystkich segmentach zróżnicowanego systemu, nie musiałaby podlegać stresom skomplikowanych procedur awansowych, które w całej Europie w instytucjach bardziej badawczych opierają się na osiągnięciach naukowych. Taka stopniowa segmentacja systemu i stratyfikacja profesji akademickiej już drobnymi krokami postępuje - w ma- 
łej skali widać ją po dystrybucji środków finansowych przez Narodowe Centrum Nauki (46\% środków jest przyznawanych pięciu najlepszym uniwersytetom). Niekwestionowani zwycięzcy marszu po krajowe środki na badania to z czasem niekwestionowani kandydaci na instytucje o nastawieniu badawczym. Krajowe i międzynarodowe efekty starań o fundusze na badania tworzą coraz bardziej wyraźną geografię produkcji wiedzy, która w gruncie rzeczy pokrywa się z geografią akademickiego prestiżu. Tylko zróżnicowanie systemu jako całości pozwoli na stopniowe wyrównywanie warunków (ekonomia czasu i poziom płac), w jakich pracuje polska kadra nastawiona na światowy obieg w nauce.

Dzisiaj różnice dystrybucji czasu przeznaczanego na kształcenie i badania między Polską a krajami Europy Zachodniej są kolosalne i po części tłumaczą, dlaczego tak słabo wypadamy w konkurencji o indywidualne, konkurencyjne środki europejskie przeznaczane na naukę (zob. dane w Kwiek 2015e). Podczas gdy w Austrii, Finlandii, Szwajcarii, Norwegii czy w Niemczech młodzi naukowcy (do 40. roku życia) pracujący na uniwersytetach spędzają średnio 20-25 godzin tygodniowo na działalność związaną z prowadzeniem badań, w Polsce ta sama grupa wiekowa kadry na tę samą działalność poświęca średnio zaledwie 14 godzin. Jednocześnie podczas gdy młodzi badacze w badanych systemach zachodnich poświęcają na kształcenie studentów średnio 6-9 godzin tygodniowo, ich polscy koledzy spędzają na działalności kształceniowej niemal trzy razy więcej czasu (średnio 19,5 godziny).

Ponadto, co nie mniej ważne, polskie uczelnie rekrutują młodych ludzi, którzy już u progu kariery są nauką średnio o wiele mniej zainteresowani niż ich zachodni koledzy. Kombinacja dwóch czynników: dystrybucji czasu pracy i poziomu orientacji na badania powoduje - w sposób nieunikniony - niską produktywność badawczą tego segmentu kadry akademickiej. Pod względem postaw akademickich (wyrażanych w orientacji wobec ról związanych z kształceniem/badaniami) możemy pokazać w Polsce wyłaniający się wzorzec, który jest zupełnie niezgodny z wzorcem zachowań akademickich charakteryzującym główne systemy europejskie. Tylko co piąty polski młody naukowiec zatrudniony na uniwersytecie $(18,1 \%)$ wskazał zainteresowanie przede wszystkim badaniami (oraz zaledwie $6 \%$ naukowców mających 50 i więcej lat). Średni poziom ukierunkowania na badania naukowe wśród polskiej kadry akademickiej w sektorze uniwersyteckim w $2010 \mathrm{r}$. (12,2\%) powrócił do niskiego poziomu z lat 80. (12,9\% w 1984 r.), po osiągnięciu swojego szczytu na poziomie 16,7\% w 1993 r. (Wnuk-Lipińska 1995: 99). A jeśli zastosować szersze podejście (a zatem połączyć odpowiedź „dydaktyka i badania, ze wskazaniem na badania” z „przede wszystkim badania”), to ów średni poziom $\mathrm{w}$ istocie obniżył się $\mathrm{w}$ ciągu ostatnich trzech dekad o ponad 10 p.p. (z poziomu $73,6 \%$ w 1984 r. do $71,5 \%$ w 1993 r. i 62,5\% w 2010 r.).

To niepokojące dane uśrednione na dużej próbie $(N=3704)$ - polski sektor uniwersytecki jest znacznie mniej ukierunkowany na badania niż ten sam sektor 
w Europie Zachodniej; co więcej, i co najbardziej alarmujące, w dłuższej perspektywie historycznej zmienia się w przeciwnym kierunku niż systemy zachodnioeuropejskie (Teichler, Arimoto i Cummings 2013; Shin i in. 2014). Zachodnie systemy uniwersyteckie stają się coraz silniej zorientowana na badania (czego wyrazem jest rosnące zainteresowanie badaniami przez kadrę akademicką), natomiast polski system jest coraz mniej zorientowany na nie. Głoszona powszechnie przez niemal dwie dekady teza o wyjątkowości polskich uniwersytetów w skali europejskiej i tym samym o braku konieczności ich głębszego reformowania, w powiązaniu z dramatycznie niskim poziomem finansowania badań naukowych i koncentracją na kształceniu, doprowadziły do paradoksalnej sytuacji, w której polscy naukowcy są dzisiaj znacznie mniej zainteresowani nauką niż w połowie lat 80 .

Młoda polska kadra jest średnio dwukrotnie rzadziej zainteresowana „przede wszystkim" badaniami niż jej zachodni koledzy - w Anglii odsetek ten wynosi ponad połowę, w Norwegii i Finlandii prawie połowę, a w Austrii, Niemczech, Holandii i Szwajcarii - ponad jedną trzecią kadry zatrudnionej w sektorze uniwersyteckim. Młodzi polscy naukowcy albo nie wykazują chęci, albo nie mają możliwości (albo i jedno, i drugie) uczestniczenia w produkcji i dystrybucji wiedzy. Z czysto ilościowego punktu widzenia wiemy zatem, że młodzi polscy naukowcy zajmują się zbyt intensywnie kształceniem studentów w porównaniu ze swoimi zachodnioeuropejskimi kolegami i m.in. dlatego cechuje ich niska produktywność badawcza. Jednak to proste ilościowe wyjaśnienie zachowań akademickich, oparte na analizie dystrybucji czasu pracy, nie sprawdza się, jeśli wziąć pod uwagę starsze pokolenia. Kadra zachodnich uniwersytetów poświęca w starszym wieku coraz więcej czasu na kształcenie i jednocześnie dużo więcej publikuje, nie tylko w porównaniu z polską kadrą (według grup dziedzin akademickich), ale przede wszystkim w porównaniu z młodszymi kolegami w swoich systemach. Ponadto starsze pokolenia naukowców w Polsce są znacznie mniej ukierunkowane na badania.

Mieliśmy przez dwie dekady do czynienia z niezwykle szkodliwym splotem akademickich - indywidualnych i instytucjonalnych - interesów i sprzężoną z nimi polityką rekrutacyjną i polityką awansową: przyjmowani do pracy młodzi ludzie nie zawsze musieli być szczególnie zainteresowani prowadzeniem badań naukowych; a młodsi, już pracujący nie zawsze musieli wykazywać się specjalnymi osiągnięciami naukowymi. Można powiedzieć, że na polskich uniwersytetach panowała, i wciąż jeszcze panuje, doskonała symbioza poziomu możliwości, jakimi dysponowała młoda kadra, i poziomu naukowych oczekiwań wobec niej (np. okres 12-16 lat na zrobienie habilitacji). Przy panującym obecnie w Polsce modelu dystrybucji czasu pracy oraz przekonaniach o rolach akademickich - promujących kształcenie kosztem prowadzenia badań - szanse na widzialność polskiej nauki w światowym obiegu naukowym są niewielkie. Niezbędne zmiany są długotrwałe i wymagają m.in. promocji nowego typu kadry w bardziej zróżnicowanym systemie. 


\section{Permanentna konkurencja jako istota nauki}

Poziom zrozumienia dla nowych, konkurencyjnych mechanizmów finansowania nauki i publikowania jej wyników, zrozumienia dla szerszej idei, wedle której nauka jest przedsięwzięciem niezwykle konkurencyjnym, nie jest w Polsce wysoki. A nie ma nauki bez bezlitosnej konkurencji - o wyniki, prestiż, odkrycia i publikacje (Hagstrom 1965; Stephen i Levin 1992; Zuckerman 1996). Idea konkurencji w nauce w ostatnich dekadach była w Polsce niemal nieobecna, a z pewnością nie stanowiła fundamentu myślenia o pracy akademickiej. Podziały wśród kadry wynikające z bardziej i mniej konkurencyjnego dorobku naukowego niemal nie istniały, podobnie jak nie prowadziły do poważniejszych różnic w prestiżu i w dostępie do zasobów (pensji, funduszy na badania czy infrastruktury). W tym samym jednak czasie (Wilson 1942; Lazarsfeld i Thielens 1958) utrwalało się w badaniach szkolnictwa wyższego przekonanie, że rozwój nauki opiera się na poszukiwaniu uznania i prestiżu przez naukowców, ich zespoły badawcze, zatrudniające ich instytuty, wydziały i uniwersytety, a te rodzą się najlepiej w warunkach stałej konkurencji o najzdolniejsze umysły, najlepsze warunki pracy i najszerzej znane publikacje (Kwiek 2017a). Przekonanie o fundamentalnej roli konkurencji w nauce wzmacniały kolejne prace z socjologii nauki i socjologii szkolnictwa wyższego oparte na badaniach empirycznych prowadzonych najpierw w Stanach Zjednoczonych, a potem w Wielkiej Brytanii (Gaston 1978; Cole i Cole 1973; Merton 1968; Zuckerman 1996). Dzisiaj idee te są wzmacniane w całym świecie z jednej strony przez globalne rankingi instytucjonalne, zwłaszcza najbardziej prestiżowe z nich, czyli oparte na danych dotyczących publikacji, a z drugiej - przez rosnącą rolę bibliometrii w ocenie indywidualnego dorobku naukowego na potrzeby finansowania grantowego.

Młoda kadra akademicka musi być coraz bardziej świadoma, iż konkuruje w równej mierze z kolegami ze swoich instytutów i z kolegami z instytutów zachodnich o bardzo ograniczone miejsce w najlepszych czasopismach naukowych, o krajowe i międzynarodowe fundusze na badania naukowe, o stanowiska postdoków w najlepszych zachodnich ośrodkach badawczych oraz o wiele innych oznak naukowego prestiżu i akademickiego uznania. Dla własnego dobra i w celu zwiększania swoich szans na przetrwanie (i osiągnięcie sukcesu) w globalizującej się nauce nie powinna wierzyć w idee nauki funkcjonującej poza konkurencją, czyli w oderwaniu od nauki uprawianej przez innych i gdzie indziej. Świat akademicki walczy o globalny prestiż: poszukują go ludzie i instytucje, a wspierają krajowe systemy finansowania nauki. Konkurencja globalna, międzynarodowa, krajowa, instytucjonalna, wydziałowa i indywidualna rośnie; nieprzyjmowanie jej do wiadomości to gwarancja międzynarodowej porażki (jak w przypadku grantów z ERC). 
Polska przechodzi właśnie najbardziej intensywne zmiany w swojej historii uprawiania nauki i musi dopasowywać swoje strategie do strategii dominujących w rozwiniętym świecie zachodnim, bo z nim jest w bezpośredniej konkurencji. Młode pokolenie nie powinno wierzyć, że będzie mogło w spokoju prowadzić badania i publikować ich wyniki w niekonkurencyjnym, nieczytanym (i w tym sensie w zasadzie dla rozwoju nauki nieistotnym) lokalnym obiegu naukowym; że będzie mogło pozostawać na marginesie dyskusji, które toczą się w obiegu zachodnich czasopism i książek; że będzie mogło prowadzić badania naukowe tylko w Polsce i tylko w Polsce prezentować ich wyniki, w ramach lokalnych czy krajowych konferencji naukowych; że będzie mogło publikować sporadycznie i tylko po polsku, w zależności od własnych chęci, w odpowiadającym mu rytmie i tempie.

Młodzi naukowcy pracują pod coraz większą presją instytucjonalną i - jak się wydaje - dopiero zaczynają rozumieć, że konkurencja w poszukiwaniu finansowania badań naukowych i w publikowaniu ich wyników na świecie stanowi konstytutywny element profesji akademickiej, wciąż rozdartej w Polsce między przebrzmiałym ideałem traktowania badań naukowych jako dodatku do kariery akademickiej, skoncentrowanej przede wszystkim na kształceniu studentów, a nowym dla polskich uczelni ideałem, w którym badania naukowe znajdują się w samym sercu akademickiego powołania. Dodajmy od razu: powołania na najlepszych uniwersytetach publicznych i niekoniecznie w dolnych segmentach systemu szkolnictwa wyższego.

Zróżnicowane systemy rozdzielają zadania według potrzeb i możliwości, a te zupełnie inaczej wyglądają z perspektywy najlepszych uczelni zlokalizowanych w dużych ośrodkach akademickich, a inaczej z perspektywy małych, regionalnych uczelni położonych z dala od akademickich centrów. Pierwszy z tych ideałów obejmuje również półfeudalne stosunki akademickie oparte na zasadach senioralności i wysoce subiektywnych kryteriach awansu naukowego, drugi zaś zawiera marzenie podzielane przez co najmniej część młodych naukowców, dotyczące desubiektywizacji kryteriów oceny na wszystkich etapach kariery akademickiej i kryteriów przyznawania finansowania na badania naukowe.

\section{Konkluzje i zaproszenie do lektury}

Silna segmentacja i przyspieszone różnicowanie polskiego systemu są niezbędne - muszą w systemie istnieć miejsca, w których jest oczywiste, że najważniejszym elementem pracy akademickiej są prestiżowe publikacje naukowe. Muszą zarazem istnieć miejsca, w których intensywność publikowania jest znikoma, a kadra koncentruje się na kształceniu studentów. Ton nauce nadają zawsze miejsca pierwsze i tam powstaje większość najcenniejszych publikacji i innych osiągnięć naukowych. Segmentacja i zróżnicowanie systemu prowadzą, rzecz jasna, w spo- 
sób nieunikniony do zakwestionowania tradycyjnego, humboldtowskiego modelu uniwersytetu, którego ważnym wymiarem była jedność kształcenia i badań naukowych. Mamy jednak do czynienia z fikcją tego ideału w masowym szkolnictwie wyższym - i tym samym pojawia się konieczność jak najszybszej z niego rezygnacji.

Tradycyjne strategie przetrwania w nowej akademii (w tym jej kontestacja) od zawsze stosowane w różnych częściach Europy, również w Polsce - nie sprawdzają się w przypadku młodej kadry. To ona najwięcej traci, ponieważ to ją w największym stopniu dotyka kumulatywny charakter dorobku naukowego. Młoda kadra zdaje sobie coraz lepiej sprawę, że nie przetrwa w nauce, nawet w nauce polskiej, bez międzynarodowego obiegu naukowego i badawczego, bez zewnętrznego finansowania swoich badań i bez koncentracji na publikacjach w prestiżowych czasopismach międzynarodowych (dokładnie tak, jak to się dzieje w przypadku ich europejskich kolegów; Kwiek i Antonowicz 2015).

Wyłaniający się w Polsce od czasu reform Kudryckiej konflikt między wizją uniwersytetu podzielaną przez wspólnotę akademicką (uniwersytet oparty na tradycyjnych wartościach akademickich jako wspólnota badaczy) a jego wizją podzielaną przez wspólnotę reformatorów i decydentów politycznych (uniwersytet pozostający pod wpływem zewnętrznych interesariuszy) ma znaczenie fundamentalne. To konflikt o podstawowe wartości (Bowen i Schuster 1986: 53). Podczas gdy w systemach zachodnioeuropejskich konflikt ten ma tradycję sięgającą kilku dekad (Maassen i Olsen 2007), w Polsce dopiero zaczyna przybierać na sile. Najbardziej kolegialny i najmniej otwarty na otoczenie zewnętrzne system w Europie (Kwiek 2015d) czekają reformy dostosowujące go do większości systemów europejskich i nieodmiennie prowadzące, zgodnie z logiką zmian organizacji, do dalszych reform.

Największą nadzieją na pozytywne zmiany będą pokolenia badaczy wychowywane w nowej, umiędzynarodowionej rzeczywistości instytucjonalnej. To z myślą o nich wprowadzano poprzednie reformy i to oni mieli być ich największym beneficjentem. Niestety założenia reform Kudryckiej zostały osłabione, a najważniejsze mechanizmy selekcyjne czy awansowe - rozmontowane; za nowymi mechanizmami konkurencyjnego finansowania nie pojawiły się też radykalnie większe środki finansowe (przykładem Krajowe Naukowe Ośrodki Wiodące i NCN). Nowa fala reform ma szansę wzmocnić ich ogólny kierunek przyjęty na początku dekady (jak choćby konkurencja i umiędzynarodowienie): ciągłość polityki wobec sektora akademickiego jest niezbędna.

Prezentowany tom jest wyjątkowy z kilku powodów. Po pierwsze, jest jubileuszowy (50/2017), po drugie, jedyny raz został oddany do dyspozycji wybitnych naukowców i administratorów, którzy nie zajmują się naukowymi badaniami szkolnictwa wyższego. Zadecydowały o tym względy praktyczne - chcieliśmy mianowicie, aby w momencie debat o reformach część z nich utrwalić, zestawić ze 
sobą w jednym miejscu, pokazać obok siebie. Napisało dla nas grono wybitne, które jak dotąd nigdy nie zaistniało w jednym miejscu. Uznaliśmy że taki jednorazowy wyłom w charakterze pisma jest istotny dla powodzenia reform, dzisiaj i w przyszłości, zgodnie z tezą o ich permanentnym charakterze.

Napisali dla nas byli i obecni dyrektorzy i prezesi największych instytucji finansujących badania naukowe (Maciej Żylicz z Fundacji na rzecz Nauki Polskiej oraz Zbigniew Błocki i Andrzej Jajszczyk z Narodowego Centrum Nauki); byli i aktualni przewodniczący Konferencji Rektorów Akademickich Szkół Polskich (Wiesław Banyś i Jan Szmidt); prezes, wiceprezes i członkowie zespołu pracującego nad ideą uniwersytetu Polskiej Akademii Nauk (Jerzy Duszyński, Tadeusz Burczyński, Paweł M. Rowiński i Andrzej Rychard); prorektorzy trzech najlepszych polskich uniwersytetów (Maciej Duszczyk z Uniwersytetu Warszawskiego, Stanisław Kistryn z Uniwersytetu Jagiellońskiego oraz Beata Mikołajczyk i Ryszard Naskręcki z Uniwersytetu im. Adama Mickiewicza); prezes Fundacji Rektorów Polskich i przewodniczący Rady Głównej Nauki i Szkolnictwa Wyższego (Jerzy Woźnicki); członkowie Komitetu Ewaluacji Jednostek Naukowych (Jerzy Brzeziński i Stefan Jackowski) i wiceprezes Polskiej Komisji Akredytacyjnej (Łukasz Sułkowski); były wiceminister ds. kontaktów uczelni z gospodarką (Jacek Guliński); wreszcie przewodniczący i członkowie Rady Narodowego Kongresu Nauki (Jarosław Górniak, Janusz M. Bujnicki, Mirosława El Fray i Aneta Pieniądz) oraz dyrektor jednego z najlepszych polskich ośrodków naukowych (Jacek Kuźnicki). Wielu z nich występuje i występowało w kilku rolach.

Wszystkim im jestem ogromnie wdzięczny. Poświęcili swój czas i swoją energię, wierząc w sukces tego przedsięwzięcia. Tym bardziej należy im się nasza czytelnicza uwaga. Istotny jest też kontekst, w którym prezentowany tom powstawał - na zakończenie cyklu debat w ramach Kongresu Nauki Polskiej i przed jego ostatnią, podsumowującą konferencją. Wszyscy autorzy (w tym redaktor tego tomu) uwierzyli, że warto zaprezentować swoje poglądy na różne - mniej i bardziej ogólne - aspekty reformowania polskiej akademii właśnie teraz, kiedy wydaje się, że będziemy mieli do czynienia z drugą falą reform. W momencie oddawania tego tomu do druku ich kształt jest nieznany, podobnie jak nieznany jest los nowej ustawy o szkolnictwie wyższym w parlamencie. Odpowiedzi kierunkowe i szczegółowe poznamy w ciągu najbliższego roku.

prof. dr hab. Marek Kwiek

\section{Podziękowania}

Prezentowany numer pisma nie ukazałby się bez wsparcia udzielonego w ramach kierowanych przeze mnie projektów Fundacji na rzecz Nauki Polskiej MISTRZ (subsydium profesorskie umowa 5/2015, 2016-2018) oraz Ministerstwa Nauki i Szkolnictwa Wyższego „Doskonałość na- 
ukowa: konkurencyjność, mierzalność, umiędzynarodowienie (EXCELLENCE)” (Dialog: umowa 0021/DLG/2016/10). Jestem wdzięczny obydwu instytucjom.

\section{Literatura}

Altbach, Ph.G. (red.) (2002). The Decline of the Guru: The Academic Profession in Developing and Middle-Income Countries. Chestnut Hill: CIHE Boston College.

Amaral, A., Bleiklie, I., Musselin, Ch. (red.) (2008). From Governance to Identity. Dordrecht: Springer.

Antonowicz, D. (2015). Między siłą globalnych procesów a lokalną tradycją. Polskie szkolnictwo wyższe $w$ dobie przemian. Toruń: Wyd. Naukowe UMK.

Antonowicz, D. (2016). Digital Players in an Analogue World: Higher Education in Poland in the Post-Massification Era. W: B. Jongbloed, H. Vossensteyn (red.), Access and Expansion Post-Massification. Opportunities and Barriers to Further Growth in Higher Education Participation (63-81). London: Routledge.

Antonowicz, D., Brdulak, J., Hulicka, M., Jędrzejewski, T., Kowalski, R., Kulczycki, E., Szadkowski, K., Szot, A., Wolszczak-Derlacz, J., Kwiek, M. (2016). Reformować? Nie reformować? Szerszy kontekst zmian w szkolnictwie wyższym. Nauka, 4: 7-33.

Antonowicz, D., Brzeziński, J.M. (2013). Doświadczenia parametryzacji jednostek naukowych z obszaru nauk humanistycznych i społecznych 2013 - z myślą o parametryzacji 2017. Na$u k a, 4: 1-35$.

Antonowicz, D., Kwiek, M., Westerheijden, D.F. (2017). The Government Response to the Private Sector Expansion in Poland. W: H. de Boer, J. File, J. Huisman, M. Seeber, M. Vukasovic, D. F. Westerheijden (red.), Policy Analysis of Structural Reforms in Higher Education (119138). Dordrecht: Springer.

Białecki, I. (2008). Międzynarodowe badania, debata i polityka edukacyjna. Nauka i Szkolnictwo Wyższe, 1(31): 22-33.

Białecki, I., Dąbrowa-Szefler, M. (2009). Polish Higher Education in Transition. Between Policy Making and Autonomy. W: D. Palfreyman, T. Tapper (red.), Structuring Mass Higher Education. The Role of Elite Institutions (183-199). London: Routledge.

Bolecki, W., Żylicz, M. (2007). Reforma sektora nauki. Nauka Polska, 16: 1-7.

Bonaccorsi, A., Daraio, C. (red.) (2007). Universities and Strategic Knowledge Creation. Specialization and Performance in Europe. Cheltenham: Edward Elgar.

Bowen, H.R., Schuster, J.H. (1986). American Professors. A National Resource Imperiled. New York - Oxford: Oxford University Press.

Brown, Ph., Lauder, H., Ashton, D. (2011). The Global Auction. The Broken Promises of Education, Jobs, and Incomes. Oxford: Oxford University Press.

Brunsson, N. (2009). Reform as Routine. Organizational Change and Stability in the Modern World. Oxford: Oxford University Press.

Brzeziński, J.M. (2014). Trzy pomysły na naprawę szkolnictwa wyższego w Polsce (kontekst nauk społecznych). W: W. Ambroziak (red.), Edukacja, uniwersytet, oświata dorostych. Studia z pedagogiki ofiarowane Profesorowi Kazimierzowi Przyszczypkowskiemu (213231). Poznań: Wyd. Naukowe UAM. 
Brzeziński, J.M. (2015). Ocena parametryczna jednostek naukowych po nowemu. W: J. Woźnicki (red.), Deregulacja $w$ systemie szkolnictwa wyższego. Program rozwoju szkolnictwa wyższego do 2020 r. Część V (125-139). Warszawa: FRP-KRASP.

Bush, V. (1945). Science: The Endless Frontier. A Report to the President on a Program forPostwar Scientific Research. Washington: United States Government Printing Office.

Clancy, P., Dill, D.D. (red.) (2009). The Research Mission of the University. Policy Reforms and Institutional Response. Rotterdam - Boston - Taipei: Sense.

Clark, B. R. (1998). Creating Entrepreneurial Universities. Organizational Pathways of Transformation. New York: Pergamon Press.

Clark, B. R. (1977). Academic Power in Italy. Bureaucracy and Oligarchy in a National University System. Chicago: University of Chicago Press.

Cole, J. R., Cole, S. (1973). Social Stratification in Science. Chicago: University of Chicago Press.

Czarnecki, K. (2013). Nowe Zarządzanie Publiczne a reforma szkolnictwa wyższego w Polsce. Praktyka Teoretyczna, 1(7): 85-106.

Dąbrowa-Szefler, M. (2009). Diagnoza stanu szkolnictwa wyższego oraz wyzwania i cele systemu zawarte w raporcie Tertiary Education for the Knowledge Society. Nauka i Szkolnictwo Wyższe, 1(33): 56-78.

EY/IBNGR (2010). Strategia rozwoju szkolnictwa wyższego do 2020 roku. Warszawa: MNiSW.

Fulton, O., Santiago, P., Edquist, Ch., El-Khawas, E., Hackl, E. (2007). OECD Reviews of Tertiary Education. Poland. Paris: OECD.

Gaston, J. (1978). The Reward System in British and American Science. New York: Wiley \& Sons.

Geuna, Aldo (1999). The Economics of Knowledge Production. Funding and Structure of University Research. Cheltenham: Edward Elgar.

Gornitzka, Å., Kogan, M., Amaral, A. (red.) (2005). Reform and Change in Higher Education. Analysing Policy Implementation. Dordrecht: Springer.

Gouldner, A. (1957). Cosmopolitans and Locals: Toward an Analysis of Latent Social Rules. Administrative Science Quarterly, 2: 281-306.

Górniak, J. (red.) (2015a). Diagnoza szkolnictwa wyższego. Program rozwoju szkolnictwa wyższego do 2020 r. Część III. Warszawa: FRP-KRASP.

Górniak, J. (2015b). Ogólne uwarunkowania sytuacji szkolnictwa wyższego w Polsce. W: J. Górniak (red.), Diagnoza szkolnictwa wyższego. Program rozwoju szkolnictwa wyższego do 2020 r. Część III (25-36). Warszawa: FRP-KRASP.

Hagstrom, W.O. (1965). The Scientific Community. New York: Basic Books.

Høj, J., Galasso, V., Nicoletti, G., Dang, T.T. (2006). The Political Economy of Structural Reform: Empirical Evidence from OECD Countries. OECD Economics Department Working Papers, 501, Paris: OECD.

Izdebski, H. (2015). Przepisy ustawy Prawo o szkolnictwie wyższym odnoszące się do systemu szkolnictwa wyższego oraz ustroju i organizacji uczelni, które mogłyby podlegać procesowi deregulacji. W: J. Woźnicki (red.), Deregulacja $w$ systemie szkolnictwa wyższego. Program rozwoju szkolnictwa wyższego do 2020 r. Część V (81-98). Warszawa: FRP-KRASP.

Jajszczyk, A. (2009). Polska w obliczu globalizacji szkolnictwa wyższego. Kultura/Polityka, 5: $73-85$.

Jajszczyk, A. (2013). Polskie uczelnie - czas na jakość. W: J. Woźnicki (red.), Misja i stużebność uniwersytetu $w$ XXI wieku (218-226). Warszawa: ISW-FRP. 
Jurek, W. (2015). Uwagi o kosztach kształcenia w kontekście kosztochłonności różnych kierunków studiów i algorytmie podziału środków publicznych na kształcenie wyższe. W: J. Wilkin (red.), Finansowanie szkół wyższych ze środków publicznych. Program rozwoju szkolnictwa wyższego do 2020 r. Część IV (96-106). Warszawa: FRP-KRASP.

Kędzierski, M. (red.) (2009). Szkolnictwo wyższe w wybranych krajach świata. Kraków: Wyd. Uniwersytetu Jagiellońskiego.

KRASP (2009). Polskie szkolnictwo wyższe. Stan, uwarunkowania i perspektywy. Warszawa: Wyd. Uniwersytetu Warszawskiego.

Krücken, G., Kosmützky, A., Torka, M. (red.) (2007). Towards a Multiversity? Universities between Global Trends and National Traditions. Bielefeld: Transcript Verlag.

Kulczycki, E. (2017). Assessing publications through a bibliometric indicator: The case of comprehensive evaluation of scientific units in Poland. Research Evaluation. 16(1): 41-52.

Kulczycki, E., Korzeń, M., Korytkowski, P. (2017). Toward an excellence-based research funding system: Evidence from Poland. Journal of Informetrics. 11(1): 282-298.

Kwiek, M. (2012). Changing Higher Education Policies: From the Deistitutionalization to the Reinstitutionalization of the Research Mission in Polish Universities. Science and Public Policy, 39(5): 641-654.

Kwiek, M. (2013). From System Expansion to System Contraction: Access to Higher Education in Poland. Comparative Education Review, 56(3): 553-576.

Kwiek, M. (2015a). Młoda kadra: różnice międzypokoleniowe w pracy naukowej i produktywności badawczej. Czym Polska różni się od Europy Zachodniej? Nauka, 3: 51-88.

Kwiek, M. (2015b). Uniwersytet $w$ dobie przemian. Instytucje $i$ kadra akademicka $w$ warunkach rosnacej konkurencji. Warszawa: Wyd. Naukowe PWN.

Kwiek, Marek (2015c). The Internationalization of Research in Europe. A Quantitative Study of 11 National Systems from a Micro-Level Perspective. Journal of Studies in International Education, 19(4): 441-359.

Kwiek, M. (2015d). The unfading power of collegiality? University governance in Poland in a European comparative and quantitative perspective. International Journal of Educational Development, 43: 77-89.

Kwiek, M. (2015e). Academic Generations and Academic Work: Patterns of Attitudes, Behaviors, and Research Productivity of Polish Academics after 1989. Studies in Higher Education. doi. 10.1080/03075079.2015.1060706.

Kwiek, M. (2016a). Constructing Universities as Organizations. University Reforms in Poland in the Light of Institutional Theory. W: E. Samier (red.), Ideologies in Educational Administration and Leadership (193-216). New York: Routledge.

Kwiek, M. (2016b). From Privatization (of the Expansion Era) to De-privatization (of the Contraction Era). A National Counter-trend in a Global Context. W: S. Slaughter, B.J. Taylor (red.), Higher Education, Stratification, and Workforce Development. Competitive Advantage in Europe, the US and Canada (311-329). Dordrecht: Springer.

Kwiek, M. (2017a). Academic Top Earners. Research Productivity, Prestige Generation and Salary Patterns in European Universities. Science and Public Policy. scxo20, https://doi. org/10.1093/scipol/scx020.1-13.

Kwiek, M. (2017b). A Generational Divide in the Polish Academic Profession. A Mixed Quantitative and Qualitative Approach. European Educational Research Journal, 17: 1-26. 
Kwiek, M., Antonowicz, D., Brdulak, J., Hulicka, M., Jędrzejewski, T., Kowalski, R., Kulczycki, E., Szadkowski, K., Szot, A., Wolszczak-Derlacz, J. (2016). Projekt założeń do ustawy Prawo o szkolnictwie wyższym. Poznań: Uniwersytet im. Adama Mickiewicza.

Kwiek, M., Antonowicz, D. (2015). The Changing Paths in Academic Careers in European Universities: Minor Steps and Major Milestones. W: T. Fumasoli, G. Goastellec, B. M. Kehm (red.), Academic Work and Careers in Europe: Trends, Challenges, Perspectives. Dordrecht: Springer.

Lam, A. (2011). What motivates academic scientists to engage in research commercialization: 'Gold, 'ribbon' or 'puzzle'? Research Policy, 40(10): 1354-1368.

Lazarsfeld, P.F., Thielens, W. (1958). The Academic Mind. Social Scientists in a Time of Crisis. Glencoe IL: Free Press of Glencoe.

Leja, K. (2008). Uniwersytet organizacją stużącą otoczeniu. W: K. Leja (red.), Spoteczna odpowiedzialność uczelni (57-69). Gdańsk: Politechnika Gdańska i Uniwersytet Gdański.

Leydessdorf, L. (2006). The Knowledge-Based Economy: Modeled, Measured, Simulated. Boca Raton: Universal Publishers.

Maassen, P. (2008). The Modernisation of European Higher Education: National Policy Dynamics. W: A. Amaral, I. Bleiklie, C. Musselin (red.), From Governance to Identity (95-112). Dordrecht: Springer.

Maassen, P., Olsen, J.P. (red.) (2007). University Dynamics and European Integration. Dordrecht: Springer.

March, J.G., Olsen, J.P. (1989). Rediscovering Institutions. The Organizational Basis of Politics. New York: Free Press.

March, J.G., Olsen, J.P. (2006). The Logic of Appropriateness. W: M. Moran, M. Rein, R.E. Goodin (red.), The Oxford Handbook of Public Policy (689-708). Oxford: Oxford University Press.

Marciniak, Z. (2016). Rekomendacje $w$ sprawie odbiurokratyzowania procesu ksztatcenia i oceny jego jakości. Warszawa: Rada Główna Nauki i Szkolnictwa Wyższego.

Martin, B., Etzkowitz, H. (2000). The Origin and Evolution of the University System. SPRU Electronic Working Paper Series, 59, December.

Merton, R. K. (1968). The Matthew Effect in Science. Science, 159(3810): 56-63.

MNiSW (2015). Program rozwoju szkolnictwa wyższego i nauki na lata 2015-2013 (autorzy opracowania: J. Górniak, Z. Marciniak, A. Kraśniewski, D. Antonowicz, J. Bujnicki). Warszawa: Ministerstwo Nauki i Szkolnictwa Wyższego.

Morawski, R.Z. (2015). Doświadczenia wybranych krajów europejskich w zakresie finansowania szkolnictwa wyższego. W: J. Wilkin (red.), Program rozwoju szkolnictwa wyższego do 2020 r. (41-53). Warszawa: Fundacja Rektorów Polskich i Konferencja Rektorów Akademickich Szkół Polskich.

Muszewska, A., Kola, A.M., Niesiołowski-Spanò, Ł., Pieniądz, A. (2015). Pakt dla Nauki, czyli jak nauka może stużyć społeczeństwu. Obywatelski projekt zmian w nauce i szkolnictwie wyższym $w$ Polsce. Warszawa.

Neave, G., Vught, F.A. van (red.) (1991). Prometheus Bound. The Changing Relationship Between Government and Higher Education in Europe. Oxford - New York: Pergamon Press.

Neave, G., Vught, F.A. van (red.) (1994). Government and Higher Education Relationships Across Three Continents. The Winds of Change. Oxford -New York: Pergamon Press. 
Nóvoa, A., Lawn, M. (2002). Fabricating Europe. The Formation of an Educational Space. Dordrecht: Kluwer.

OECD (2010). Making Reform Happen: Lessons From OECD Countries. Paris: OECD.

Olsen, J.P. (1998). Institutional Design in Democratic Contexts. W: N. Brunsson, J.P. Olsen (red.), Organizing Organizations (319-349). Copenhagen: Fagbokforlaget.

Olsen, J.P. (2007). The Institutional Dynamics of the European University. W: P. Maassen, J.P. Olsen (red.), University Dynamics and European Integration (25-54). Dordrecht: Springer.

OPI (2016). Systemy publicznego finansowania nauki w ujęciu międzynarodowym. Warszawa: Ośrodek Przetwarzania Informacji - Państwowy Instytut Badawczy.

Paradeise, C., Reale, E., Bleiklie, I., Ferlie, E. (red.) (2009). University Governance. Western European Comparative Perspectives. Dordecht: Springer.

Pfeffer, J., Salancik, G.R. (2003). The External Control of Organizations. A Resource Dependence Perspective. Stanford: Stanford University Press.

Ramirez, F.O. (2006). The Rationalization of Universities. W: M.-L. Djelic, K. Sahlin-Andersson (red.), Transnational Governance. Institutional Dynamics of Regulation (225-246). Cambridge: Cambridge University Press.

Shattock, M. (2009a). Entrepreneurialism in Universities and the Knowledge Economy. Diversification and Organizational Change in European Higher Education. Maidenhead: Open University Press - SRHE.

Shin, J.Ch., Arimoto, A., Cummings, W. K., Teichler, U. (red.) (2014). Teaching and Research in Contemporary Higher Education. Systems, Activities and Rewards. Dordrecht: Springer.

Siemińska, R., Walczak, D. (2012). Polish Higher Education: From State Toward Market, from Elite to Mass Education. Advances in Education in Diverse Communities: Research, Policy, and Praxis, 7: 197-224.

Stephan, P. (2012). Pay Inequality Makes for Better Science. Scientific American Magazine, 307(4): 5-6.

Stephan, P., Levin, S. (1992). Striking the Mother Lode in Science: The Importance of Age, Place, and Time. Oxford: Oxford University Press.

Sułkowski, Ł. (2016). Kultura akademicka. Koniec utopii? Warszawa: Wyd. Naukowe PWN.

Szadkowski, K. (2015). Uniwersytet jako dobro wspólne. Podstawy krytycznych badań nad szkolnictwem wyższym. Warszawa: Wyd. Naukowe PWN.

Szadkowski, K. (2017). The University of the Common: Beyond the Contradictions of Higher Education Subsumed under Capital. W: M. Izak, M. Kostera, M. Zawadzki (red.), The Future of University Education (39-62). Cham: Palgrave Macmillan.

Teichler, U., Arimoto, A., Cummings, W. K. (2013). The Changing Academic Profession. Major Findings of a Comparative Survey. Dordrecht: Springer.

Williams, G. (2012). Some Wicked Questions from the Dismal Science. W: P. Temple (red.), Universities in the Knowledge Economy: Higher Education Organisation and Global Change (19-37). London - New York: Routledge.

Wilkin, J. (2015). Główne uwarunkowania rozwoju szkolnictwa wyższego w Polsce. W: J. Wilkin (red.), Finansowanie szkół wyższych ze środków publicznych. Program rozwoju szkolnictwa wyższego do 2020 r. Część IV (13-19). Warszawa: FRP-KRASP.

Wilson, L. (1942/1995). The Academic Man. A Study in the Sociology of a Profession. New Brunswick, NJ: Transaction Publishers. 
Wnuk-Lipińska, E. (1995). Innowacyjność a konserwatyzm. Uczelnie polskie w procesie przemian społecznych. Warszawa: Instytut Studiów Politycznych PAN.

Wolszczak-Derlacz, J. (2015). Analiza efektywności działalności uczelni europejskich i amerykańskich - podejście nieparametryczne. Ekonomia. Rynek, Gospodarka, Spoteczeństwo, 40: 109-130.

Woźnicki, J. (2015). Deregulacja i jej rozumienie właściwe ze względu na wymogi rozwojowe szkolnictwa wyższego. W: J. Woźnicki (red.), Deregulacja $w$ systemie szkolnictwa wyższego. Program rozwoju szkolnictwa wyższego do 2020 r. Część V (57-80). Warszawa: FRP-KRASP.

Ziman, J. (1994). Prometheus Bound. Science in a Dynamic Steady-State. Cambridge: Cambridge University Press.

Zuckerman, H. (1996). Scientific Elite: Nobel Laureates in the United States. New Brunswick: Transaction Publishers.

Żylicz, M. (2012). Potrzebujemy dalszych zmian. Nauka. 3: 15-22.

Żylicz, M. (2015). Gospodarka - szkolnictwo wyższe - nauka w Polsce. Podsumowanie dyskusji prowadzonych $w$ Fundacji na rzecz Nauki Polskiej z udziatem przedstawicieli środowisk naukowego i biznesu. Warszawa: FNP [maszynopis].

CYTOWANIE: Kwiek, M. (2017). Wprowadzenie: Reforma szkolnictwa wyższego w Polsce i jej wyzwania. Jak stopniowa dehermetyzacja systemu prowadzi do jego stratyfikacji. Nauka i Szkolnictwo Wyższe. 2(50): 9-38. DOI: 10.14746/nisw.2017.2.0.

MAREK KWIEK - prof. dr hab., dyrektor Centrum Studiów nad Polityką Publiczną i kierownik Katedry UNESCO Badań Instytucjonalnych i Polityki Szkolnictwa Wyższego UAM w Poznaniu. Od piętnastu lat prowadzi rozległe międzynarodowe badania szkolnictwa wyższego. Międzynarodowy doradca w sprawach polityki szkolnictwa wyższego (OECD, KE, Rada Europy, OBWE, USAID, UNDP i Bank Światowy). Kierownik lub partner w 50 międzynarodowych projektach badawczych i doradczych. Publikuje przede wszystkim w obiegu międzynarodowym, m.in. w Science and Public Policy, Comparative Education Review, Higher Education czy Studies in Higher Education. Autor 180 artykułów, ostatnie monografie to: Uniwersytet $w$ dobie przemian. Instytucje i kadra akademicka w warunkach rosnacej konkurencji (2015), Knowledge Production in European Universities: States, Markets, and Academic Entrepreneurialism (2013) i Transformacje uniwersytetu. Zmiany instytucjonalne i ewolucje polityki edukacyjnej w Europie (2010). Członek rad redakcyjnych prestiżowych czasopism międzynarodowych: Higher Education Quarterly, European Educational Research Journal, British Educational Research Journal i European Journal of Higher Education. W latach 2012-2017 kierował projektem MAESTRO (NCN): Program Międzynarodowych Badań Porównawczych Szkolnictwa Wyższego, a w 2015 r. otrzymał subsydium profesorskie w programie MISTRZ (FNP). E-mail: kwiekm@amu.edu.pl. 